\title{
LACK OF ADAPTATION TO LOW OXYGEN PRESSURE IN AGED ANIMALS
}

\author{
E. FLÜCKIGER, D.Sc., AND F. VERZÁR, M.D.
}

(From the Physiological Institute, University of Basel, Basel, Switzerland)

Adaptation to a barometric pressure of about half an atmosphere, or the equivalent low partial oxygen pressure, necessitates various adjustments in the animal body. Respiration and circulation, as well as erythrocyte and hemoglobin production, are changed.

We found (1) it to be a very characteristic phenomenon that, in rats, after lowering the atmospheric pressure to $350 \mathrm{~mm}$. $\mathrm{Hg}$ (corresponding to $6,500 \mathrm{M}$. simulated altitude), the rectal temperature drops several degrees in a few hours. In about 4 or 5 days body temperature is restored to normal, although the pressure was kept low. It was also demonstrated (2) that rats kept at $350 \mathrm{~mm}$. $\mathrm{Hg}$ for a fortnight developed a status, which we called "retained adaptation," i. e., if these animals were brought to atmospheric pressure $(732 \mathrm{~mm} . \mathrm{Hg}$ at Basel) and within a few days returned to $350 \mathrm{~mm}$. $\mathrm{Hg}$, only a slight decrease in rectal temperature was observed. At $732 \mathrm{~mm}$. $\mathrm{Hg}$ this status of retained adaptation slowly returned to the full reaction, until, 10 days later, when exposed to $350 \mathrm{~mm}$. $\mathrm{Hg}$, the same drop of rectal temperature was seen as originally.

This drop of temperature and its restoration to normal is an objective sign of adaptation which can easily be observed. We have used this phenomenon in the present publication to investigate whether this adaptation to low pressure is the same in young, adult, and aged animals.

\section{METHODS}

The technique of these experiments was similar to that employed in our earlier studies (1). Sixty-four white male rats of our laboratory stock, 45 to 570 days old, were used in groups of 4 animals for each age level, giving a total of 16 groups. Of these, 2 groups were tested more than once: 1 group was studied when $2 \frac{1}{2}$ and $4 \frac{1}{2}$ months (70 and 135 days) old (experiments $74 \mathrm{~b}$ and $79 \mathrm{~b}$ ), and 1 gr jup was tested at the age of 12,14, and 20 months $(360,420$, and 600 days) (experiments $74 \mathrm{a}$, $79 \mathrm{a}$, and $85 \mathrm{a})$.

Submitted for publication December 15, 1954.

Published on a grant from the Forest Park Foundation to the Journal of Gerontology.
The rats were fed with a standard diet ad libitum. They were placed in a tank of about $125 \mathrm{~L}$. capacity, in which the pressure was diminished to $350 \mathrm{~mm}$. $\mathrm{Hg}$ and kept constant at about $\pm 10 \mathrm{~mm}$. $\mathrm{Hg}$. At $350 \mathrm{~mm}$. $\mathrm{Hg}$ there was an air flow through the tank of about $4.5 \mathrm{~L}$. per minute. The temperature within the tank was about $22 \mathrm{C}$. During the first 24 hours the tank was opened several times in order to observe the drop in rectal temperature. During the next days the tank was only opened once daily, the animals taken out for about 20 minutes, and their rectal temperature measured with a mercury thermometer. This was done regularly at about 10 to 11 a.m., 24 hours after the last feeding. Afterwards the rats were placed back into the tank, with fresh food and water. The tank was equipped with a window allowing observation of the behavior of the rats. The weight of the animals was taken at regular intervals and in several series also blood hemoglobin was measured by the Sahli method.

Retained adaptation was tested in 13 of the 16 groups. This was done in the following way: After a period of about 14 days of adaptation to $350 \mathrm{~mm}$. $\mathrm{Hg}$ the rats were kept at $730 \mathrm{~mm}$. $\mathrm{Hg}$ for 48 hours and then exposed again to $350 \mathrm{~mm}$. $\mathrm{Hg}$. Since retained adaptation never lasts longer than about a fortnight, there is no danger that the reaction at a later trial was influenced by the first exposure to low barometric pressure. However, the results in these groups were checked with th: other groups which were only used once.

\section{RESULTS}

The results of our experiments are tabulated as mean values for each group in table 1. There are always individual differences in each group. The drop of body temperature and the time in which normal body temperature is restored should be compared. Examples of temperature curves of different age groups are shown in figure 1 and 3 .

Table 1 shows that there is no difference in the initial drop of rectal temperaturc between young and old animals; their maximal value was $5.3 \mathrm{C}$. in 6 weeks ( 42 days) old 
Table 1. Body Temperature adaptation of Rats to Reduced Barometric Pressure.

\begin{tabular}{|c|c|c|c|c|c|c|c|c|c|c|}
\hline \multirow{3}{*}{ Series } & \multirow{3}{*}{$\begin{array}{l}\text { Age and } \\
\text { Number of } \\
\text { Animals }\end{array}$} & \multicolumn{4}{|c|}{ Adaptation } & \multicolumn{4}{|c|}{ Retained Adaptation } & \multirow{3}{*}{ Remarks } \\
\hline & & \multirow{2}{*}{$\begin{array}{c}\mathrm{Rt}^{*} \text { at } \\
\text { Beginning } \\
\left({ }^{\circ} \mathrm{C} .\right)\end{array}$} & \multirow{2}{*}{$\begin{array}{l}\text { Maximal } \\
\text { Drop of } \\
\text { Rt }\left({ }^{\circ} \mathrm{C} .\right)\end{array}$} & \multicolumn{2}{|c|}{ Rt Restored } & \multirow{2}{*}{$\begin{array}{c}\text { Rt at } \\
\text { Beginning } \\
\left({ }^{\circ} \mathrm{C} .\right)\end{array}$} & \multirow{2}{*}{$\begin{array}{l}\text { Maximal } \\
\text { Drop of } \\
\text { Rt }\left({ }^{\circ} \mathrm{C} .\right)\end{array}$} & \multicolumn{2}{|c|}{ Rit Restored } & \\
\hline & & & & Day & $\operatorname{Rt}\left({ }^{\circ} \mathrm{C}.\right)$ & & & Day & $\operatorname{Rt}\left({ }^{\circ} \mathrm{C}.\right)$ & \\
\hline 93 & $\begin{array}{c}51 / 2 \text { weeks } \\
n=7\end{array}$ & 37.5 & 4.7 & $3,-4$. & 37.2 & - & - & - & - & \\
\hline 67 & $\begin{array}{c}6 \text { weeks } \\
n=5\end{array}$ & 37.6 & 5.3 & 4. & 37.4 & 37.2 & 2.2 & 4. & 37.0 & $\begin{array}{l}72 \text { hours at } \\
730 \mathrm{~mm} . \mathrm{Hg}\end{array}$ \\
\hline $83 \mathrm{~b}$ & $\begin{array}{c}8 \text { weeks } \\
n=4\end{array}$ & 37.2 & 3.4 & 3. & 37.2 & 37.4 & 1.8 & 1. & 37.2 & \\
\hline 88 & $\begin{array}{c}8 \text { weeks } \\
n=4\end{array}$ & 37.4 & 5.2 & 7. & 37.4 & 37.0 & 2.7 & 2. & 36.9 & \\
\hline 91 & $\begin{array}{c}9 \text { weeks } \\
n=4\end{array}$ & 37.3 & 4.1 & 5. & 37.2 & - & - & - & - & \\
\hline $81 \mathrm{~b}$ & $\begin{array}{c}9 \text { weeks } \\
n=4\end{array}$ & 37.6 & 3.4 & 4. & 37.8 & 37.5 & 3.2 & 2. & 37.4 & \\
\hline $74 \mathrm{~b}$ & $\begin{array}{c}2 ! / 2 \text { months } \\
n=4\end{array}$ & 38.0 & 4.5 & 5. & 37.9 & 37.6 & 0.8 & 1. & 37.7 & \\
\hline 90 & $\begin{array}{c}3 \text { months } \\
n=4\end{array}$ & 37.3 & 4.6 & 5. & 37.3 & - & - & - & - & \\
\hline $79 \mathrm{~b}$ & $\begin{array}{c}41 / 2 \text { months } \\
n=4\end{array}$ & 38.1 & 4.9 & 5. & 38.0 & 38.0 & 3.3 & 2. & 37.8 & \\
\hline $85 \mathrm{~b}$ & $\begin{array}{c}5 \text { months } \\
n=4\end{array}$ & 73.2 & 3.4 & 4. & 37.2 & 37.2 & 1.9 & 2. & 37.1 & \\
\hline 80 & $\begin{array}{c}7 \text { months } \\
n=4\end{array}$ & 37.2 & 4.2 & 4. & 37.3 & 36.4 & 1.0 & 1. & 36.5 & \\
\hline $74 \mathrm{a}$ & $\begin{array}{c}12 \text { months } \\
n=4\end{array}$ & 38.1 & 4.7 & $\begin{array}{c}5 . \\
10 .\end{array}$ & $\begin{array}{l}36.9 \\
36.3\end{array}$ & 37.7 & 2.3 & 3. & 37.3 & no restorationt \\
\hline $83 a$ & $\begin{array}{c}14 \text { months } \\
n=2\end{array}$ & 37.4 & 3.5 & $\begin{array}{l}5 . \\
10 .\end{array}$ & $\begin{array}{l}35.8 \\
36.0\end{array}$ & 37.3 & 2.6 & 3. & 36.0 & no restoration \\
\hline $79 a$ & $\begin{array}{c}14 \text { months } \\
n=4\end{array}$ & 38.0 & 5.2 & $\begin{array}{l}5 . \\
10\end{array}$ & $\begin{array}{l}36.3 \\
36.0\end{array}$ & 37.4 & 4.1 & 2. & 35.6 & no restoration \\
\hline 89 & $\begin{array}{c}19 \text { months } \\
n=4\end{array}$ & 37.6 & 5.3 & $\begin{array}{c}5 . \\
10 . \\
16\end{array}$ & $\begin{array}{l}35.2 \\
36.1 \\
36.1\end{array}$ & 37.4 & 3.8 & 3. & 35.4 & no restoration \\
\hline $85 \mathrm{al}$ & $\begin{array}{c}20 \text { months } \\
n=4\end{array}$ & 37.2 & 4.9 & $\begin{array}{r}5 . \\
11 .\end{array}$ & $\begin{array}{l}36.6 \\
35.4\end{array}$ & 37.2 & 3.8 & 3. & 35.6 & no restoration \\
\hline
\end{tabular}


(group 67) as well as in 19 months (570 days) (group 89) old rats.

The difference between young and old rats lies in the ability to restore the original body temperature. In 40 to 210 day ( 7 months) old animals, restoration is complete in 3 to 5 days; on the third day of low pressure their rectal temperature is mostly above $37 \mathrm{C}$. and often as high as 37.8 to $38.0 \mathrm{C}$. Figure 1 shows one of these groups. The 20 rats of $12,14,19$, and 20 months of age (groups $74 a$, $83 a, 79 a, 89,85 a)$ were unable to restore their body temperature, and figure 3 is an example of how restoration of the body temperature is often at first attempted and how later it again falls. On the tenth day at low pressure body temperature was between 35.4 and $36.3 \mathrm{C}$.

Thus, in the course of aging, the rats los: the ability to restore normal body temperature at low oxygen pressures.

Retained adaptation, i. e., the reaction to $350 \mathrm{~mm}$. $\mathrm{Hg}$ of formerly adapted rats after 2 to 3 days of a pressure of $732 \mathrm{~mm}$. $\mathrm{Hg}$ to a new decreased pressure of $350 \mathrm{~mm}$. $\mathrm{Hg}$ was also different in old animals. The oldest groups (79a, 89, 85a) showed the largest drop in body temperature, as much as without a previous adaptation. More characteristic is that while the young animals restored body temperature within one to two days (fig. 2)

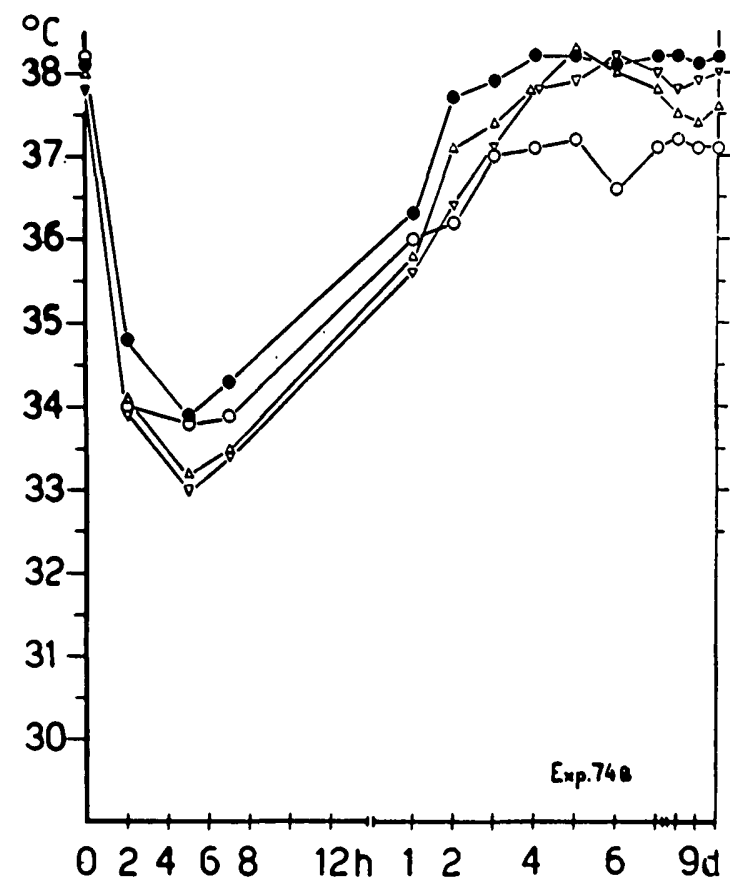

Fic. 1. Series $74 \mathrm{~b}, 4$ male rats, $2 \mathrm{t} / 2$ months old, adaptation to $350 \mathrm{~mm}$. $\mathrm{Hg}$ in 2 days. in the rats of 14, 19, and 20 months of age there was no return to normal body temperature, even after the third day of exposure to low barometric pressure. Some of the old animals died after exposure to low atmospheric pressure (fig. 4), which never occurred with young animals.

It is known that exposure to low barometric pressure, especially during the first few days, results in a decrease of body weight, or inhibits growth in young animals through a decrease of food intake (4) and the body water content (3). The data shown in table 2 are examples.

In order to characterize the influence of low barometric pressure on the different age groups by another criterion, the hemoglobin of the blood from the tip of the tail was determined in several series. In rats 2 months

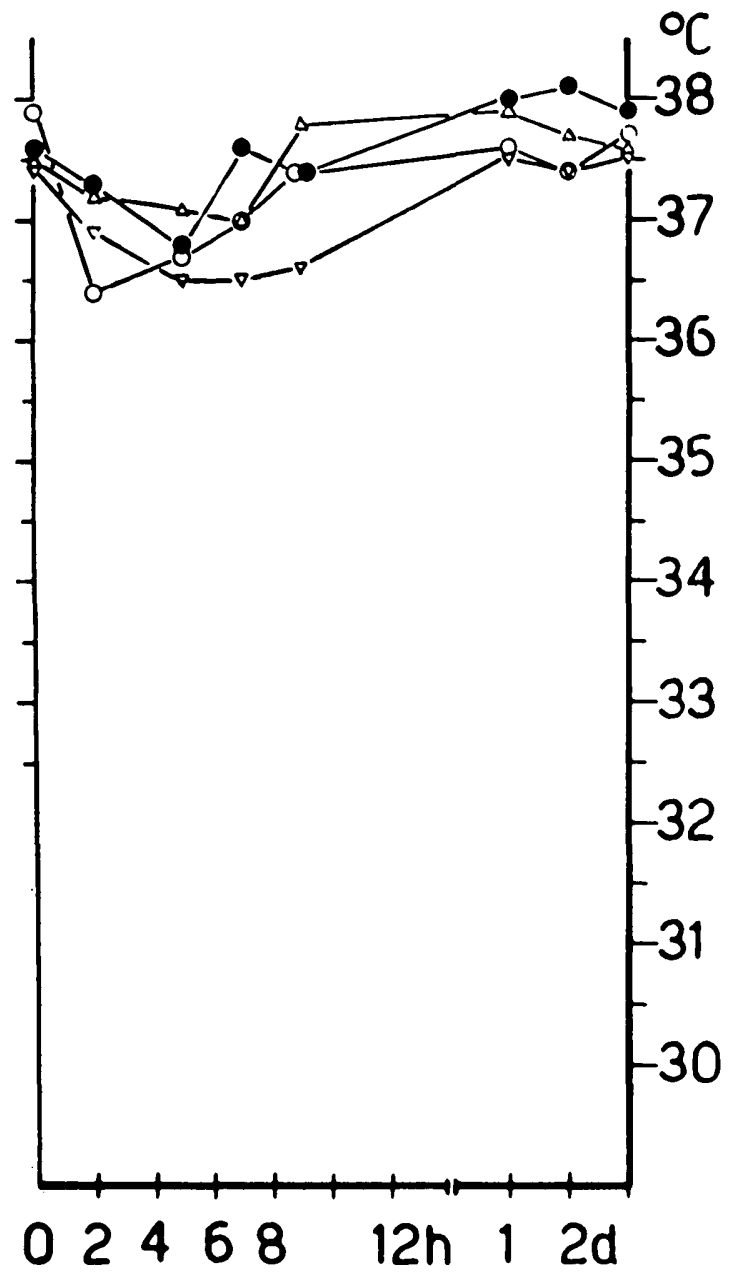

FIG. 2. Retained adaptation of the same animals (Series 74b) after 48 hours at $730 \mathrm{~mm}$. $\mathrm{Hg}$ and then again at $350 \mathrm{~mm}$. $\mathrm{Hg}$. 
Table 2. Changes in Weight of Male Rats of Different Ages Exposed to Low Oxygen Pressure.

\begin{tabular}{|c|c|c|c|c|c|}
\hline Series & $\begin{array}{l}\text { Age and } \\
\text { Number of } \\
\text { Nale Rats }\end{array}$ & $\begin{array}{c}\text { Mean } \\
\text { Initial } \\
\text { Weight (Gm.) }\end{array}$ & $\begin{array}{c}\text { Days at } \\
350 \mathrm{Mm} . \mathrm{Hg}\end{array}$ & $\begin{array}{l}\text { Mean } \\
\text { Weight } \\
\text { (Gm.) }\end{array}$ & $\begin{array}{l}\text { Difference } \\
\quad(\mathrm{Gm} .)\end{array}$ \\
\hline $83 \mathrm{~b}$ & $\begin{array}{l}2 \text { months } \\
n=4\end{array}$ & 98 & 10 & 102 & +4 \\
\hline 88 & $\begin{array}{l}2 \text { months } \\
n=4\end{array}$ & 89 & 17 & 94 & +5 \\
\hline 91 & $\begin{array}{c}9 \text { weeks } \\
n=4\end{array}$ & 115 & 15 & 108 & -7 \\
\hline 80 & $\begin{array}{c}7 \text { months } \\
n=4\end{array}$ & 216 & 10 & 202 & -14 \\
\hline $83 a$ & $\begin{array}{c}14 \text { months } \\
n=4\end{array}$ & 334 & 10 & 309 & -25 \\
\hline 89 & $\begin{array}{c}19 \text { months } \\
n=4\end{array}$ & 289 & 17 & 275 & -23 \\
\hline
\end{tabular}

old the hemoglobin changes were followed during the first 5 days by daily determinations (group 83b). It was found that an increase in hemoglobin started only on the fifth day of exposure, reaching 130-142 per cent on the tenth day $(100$ per cent $=16 \mathrm{Gm}$. hemoglobin per $100 \mathrm{cc}$.). In table 3 hemoglobin values estimated after different periods of exposure to $350 \mathrm{~mm}$. $\mathrm{Hg}$ are shown. The mean

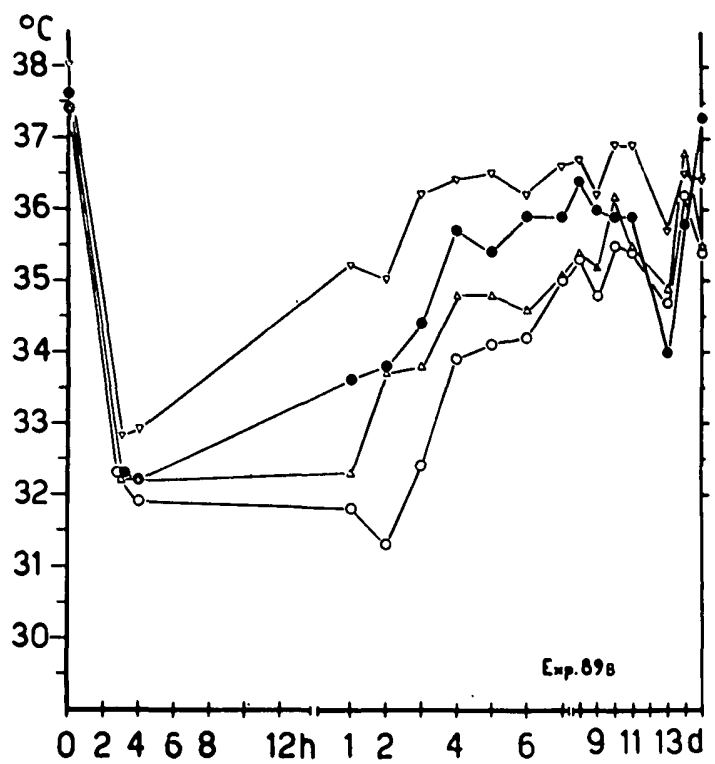

Fic. 3. Series $89 \mathrm{~b}, 4$ male rats, 19 months old, incomplete adaptation to $350 \mathrm{~mm}$. $\mathrm{Hg}$. hemoglobin content at $732 \mathrm{~mm}$. $\mathrm{Hg}$ of 14 rats 2 to 14 months old was found to be 106 per cent (range 99-115) when 100 per cent $=16 \mathrm{Gm}$. $\mathrm{Hb}$ per $100 \mathrm{ml}$. From the table

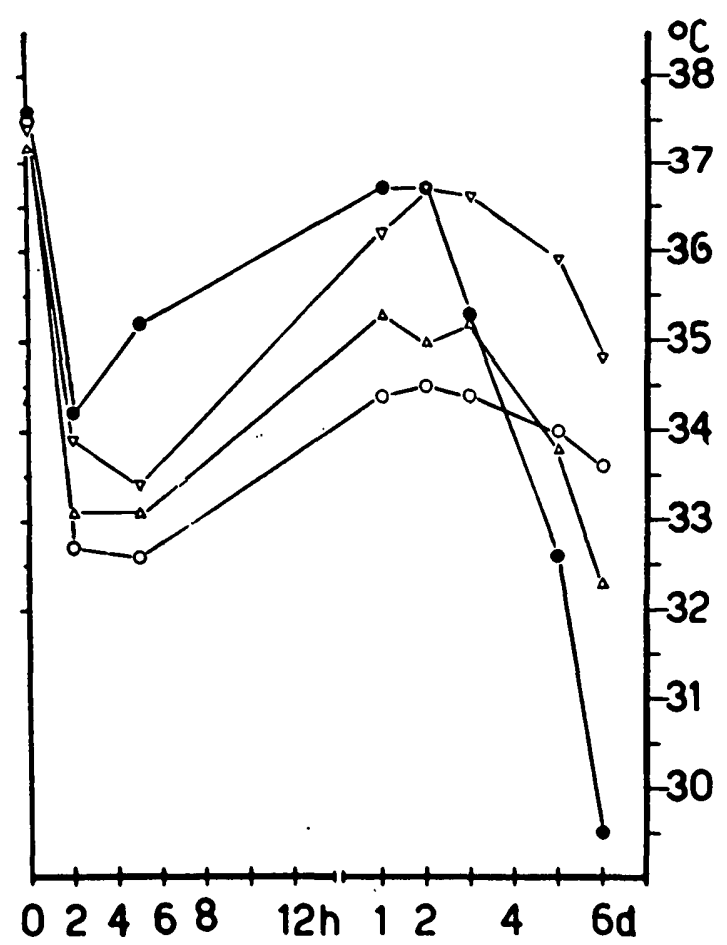

Fig. 4. No retained adaptation of the same animals (Series 89b) after 48 hours at $730 \mathrm{~mm}$. $\mathrm{Hg}$ and then again at $350 \mathrm{~mm}$. $\mathrm{Hg}$. 
Table 3. Changes in Mean Blood Hemoglobin in Male Rats at Different Ages, Exposed to Low Oxygen Pressure.

\begin{tabular}{|c|c|c|c|c|}
\hline Series & $\begin{array}{l}\text { Age and } \\
\text { Number of } \\
\text { Animals }\end{array}$ & $\begin{array}{c}\text { Days at } \\
350 \mathrm{Mm} . \mathrm{Hg}\end{array}$ & $\begin{array}{c}\text { Mean } \\
\text { Hemoglobin \% } \\
(100=16 \mathrm{Gm} . \%)\end{array}$ & $\begin{array}{c}\text { Lowest } \\
\text { and Highest } \\
\text { Value }\end{array}$ \\
\hline Controls at $732 \mathrm{~mm} . \mathrm{Hg} \ldots \ldots$ & $\begin{array}{c}2-14 \text { months } \\
n=14\end{array}$ & - & 106 & $99-115$ \\
\hline 83 b. $\ldots \ldots \ldots \ldots \ldots \ldots \ldots$ & $\begin{array}{c}2 \text { months } \\
\mathrm{n}=4\end{array}$ & $10)$ & & \\
\hline $81 \quad \ldots$ & $\begin{array}{c}9 \text { weeks } \\
n=4\end{array}$ & 10 & 137 & $125-145$ \\
\hline 70. & $\begin{array}{c}31 / 2 \text { months } \\
n=4\end{array}$ & 14 & 166 & $146-180$ \\
\hline 83 a.... & $\begin{array}{c}14 \text { months } \\
n=4\end{array}$ & 10 & 158 & $155-166$ \\
\hline 85 a............ & $\begin{array}{c}20 \text { months } \\
n=4\end{array}$ & 11 & 149 & $146-152$ \\
\hline
\end{tabular}

it follows that the capacity of the rats to increase the blood hemoglobin did not diminish up to 20 months of age (table 3 ).

\section{DISCUSSION}

It is not definitely known what causes the drop of body temperature at the beginning of the exposure to low partial oxygen pressure. Since there are no proofs of altered blood circulation under low pressure, the most probable explanation is a diminished heat production. Then in the course of adaptation of the young animals, the metabolism which is necessary for normal heat production is increased. In aged animals, however, this increase in metabolic activity to restore and maintain normal body temperature, i. e., their adaptation capacity, is diminished; they are also barely able to reach a state of adaptation which can be retained when kept at 732 $\mathrm{mm}$. Hg.

This inability to adapt to low oxygen pressure is an astonishingly early sign of aging. It is, so far, the only example of functional adaptation which disappears with age that we were able to observe.

Our experiments show at the same time that the reactivity of the bone marrow in respect to hemoglobin production under low oxygen pressure was not decreased in the old animals. This finding is in line with the results of other experiments, where no decrease in compensatory hypertrophy of the kidney or of the adrenal cortex could be seen in old animals (5).

From this point of view the demonstration of a decrease of metabolic adaptation to low oxygen pressure in aging rats becomes an especially interesting sign of aging.

\section{SUMMARY}

1. Adaptation to low barometric pressure $(350 \mathrm{~mm} . \mathrm{Hg}$ ) was studied in 64 male rats between the ages of 45 to 570 days ( 2 to 20 months).

2. Adaptation was tested by the decrease and the restoration of body temperature during 15 days' continuous exposure to a low atmospheric pressure of $350 \mathrm{~mm}$. $\mathrm{Hg}$. In addition retained adaptation was also tested after an additional study of 48 hours at normal barometric pressure $(732 \mathrm{~mm}$. $\mathrm{Hg}$ at Basel).

3. Fourteen to 20 month old rats are completely unable to restore the normal body temperature after the initial drop during the first few hours of exposure to low barometric pressure. They also show a decreased re- 
tained adaptation. This is in contrast to the findings in young animals.

4. There is no significant difference in the increase of blood hemoglobin between young and old rats in response to a 10 to 15 day exposure to $350 \mathrm{~mm}$. $\mathrm{Hg}$.

\section{REFERENCES}

1. Flückiger E., and Verzár, F.: Senkung und Restitution der Körpertemperatur bei niedrigem atmosphärischem Druck und der Einfluss von Thyreoidea, Hypophyse und Nebennierenrinde auf dieselbe. Helvet. physiol. et pharmacol. acta, 10: 349-359, 1952.
2. Flückiger, E., and Verzár, F.: Ueberdanern der Adaptation an niedrigen atmosphärischen Druck, nachgewiesen an der Wärmeregulation. Helvet. physiol. et pharmacol. acta, 11: 67-72, 1953.

3. Picon-Réategui, E., Fryers, G. R., Berlin, N. I., and Lawrence, J. H.: Effect of Reducing the Atmospheric Pressure on Body Water Content of Rats. . Am. J. Physiol., 172: 33-36, 1953.

4. Sundström, E. S., and Michaels, G.: The Adrenal Cortex in Adaptation to Altitude, Climate and Cancer. University of California Press, Berkeley and Los Angeles, 1942, p. 47

5. Verzár F., and Flückiger, E.: Adaptation to Low Atmospheric Pressure. Symposia and Abstracts, International Association of Gerontology, Third Congress, 1954, p. 263. 